\title{
New distribution record of Cybocephalus kathrynae (Coleoptera, Cybocephalidae) on Mona Island, Puerto Rico
}

\author{
Jean Carlos Curbelo-Rodríguez ${ }^{1,2}$, Elvia J. Meléndez-Ackerman ${ }^{2,3}$, \\ Julissa Rojas-Sandoval ${ }^{2,3} \&$ Alejandro Segarra-Carmona ${ }^{4}$
}

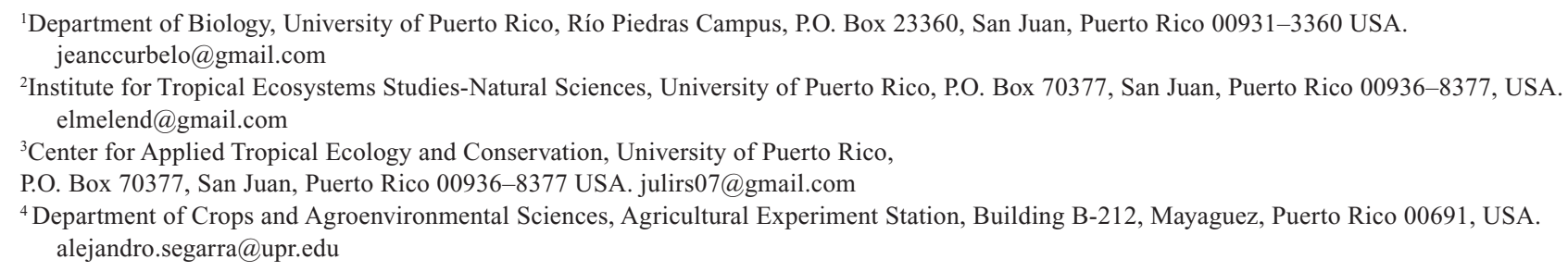

\begin{abstract}
New distribution record of Cybocephalus Kathrynae (Coleoptera, Cybocephalidae) on Mona Island, Puerto Rico. A new record of Cybocephalus kathrynae T.R. Smith (Cybocephalidae) is reported for Puerto Rico. Adults were collected from the flowers of Mammillaria nivosa (Cactaceae) on Mona Island Reserve. Prior to this study, this beetle species was only reported for Monroe and Miami-Dade Counties, Florida, USA.
\end{abstract}

KEYWORDS. Beetle; Coleoptera; Cybocephalidae; Mammillaria nivosa.

RESUMO. Novo registro de distribuição de Cybocephalus Kathrynae (Coleoptera, Cybocephalidae) na Ilha de Mona, Puerto Rico. Um novo registro de Cybocephalus kathrynae T. R. Smith (Cybocephalidae) é reportado para Puerto Rico. Os adultos foram coletados em flores de Mammillaria nivosa (Cactaceae) na Reserva da Ilha de Mona. Antes da realização deste estudo, esta espécie apenas havia sido registrada nos condados de Monroe e Miami-Dade na Florida, EUA.

PALAVRAS-CHAVE. Besouro; Coleoptera; Cybocephalidae; Mammillaria nivosa.

Here we report a new distribution record for the order Coleoptera, uncovered as part of ongoing research studies on breeding systems and flower visitors of Mammillaria nivosa Link ex N. E. Pfeiffer (Cactaceae) and pitfall traps set on Mona Island Reserve, Puerto Rico. We also include information on the beetles' interaction with $M$. nivosa from video observations that update what is known about its natural history. Adult beetles were collected from flower corollas of $M$. nivosa, where it was found in abundance (Fig. 1), and identified as Cybocephalus kathrynae T. R. Smith (Cybocephalidae; Smith \& Cave 2006). Prior to this study, this beetle species was only known from Monroe and Miami-Dade Counties, Florida (Smith \& Cave 2006).

Mammillaria nivosa is a small plant that presents unbranched globose forms with radial symmetry. It is an understory plant of shrubby vegetation, and is most abundant in open spaces. In the field, this cactus tends to aggregate, giving the visual effect of a "sea urchin colony" (Fig. 1A-B). Propagation of these plants is through seeds. Plants may reach heights of up to $25 \mathrm{~cm}$. They have pale yellow to creamcolored flowers, which reach average lengths of up to $15 \mathrm{~mm}$.
Spines are variable in length (maximum length $=38.1 \mathrm{~mm}$ ), and often overlap each other above flowers (Fig. 1C). This spatial arrangement appears defensive, likely making it difficult for large animals to interact with fruits and flowers, and where easy access is allowed only to small organisms. Flower morphology of $M$. nivosa on Mona Island Reserve shows an average stigma-anther separation length of $1.48 \mathrm{~mm}$ with stigmas always emerging above anthers, suggesting that autogamy is unlikely.

In May 2008, adults of C. kathrynae were collected near Pájaros Beach on Mona Island, and shipped to the Department of Entomology and Nematology at the University of Florida for identification. Identification was performed by Dr. T. R. Smith (who originally described the species) considering diagnostic characters from male and female genitalia. In addition, we also used data gathered from video observations and from morphological analyses of specimens using both light and scanning electron microscopy procedures. In general, C. kathrynae bodies and body parts are dark brown to black with the exception of the hind legs and antennae which are light brown (Fig. 1D). In contrast with 
Florida specimens, the elytral apices of Mona Island beetles appear lighter than the rest of the body. Mona Island specimens were also somewhat smaller in size (length: 0.73-1.0 $\mathrm{mm}$, width $0.6-0.7 \mathrm{~mm}, \mathrm{n}=10$ ) relative to Florida's specimens (length 1.3-1.6 mm, width 0.8-1.0 mm, Smith \& Cave 2006). Nevertheless, scanning electron microcopy analysis shows specimens that are very similar in shape and form to those described by Smith \& Cave (2006, Fig. 2).

Video recordings showed adult $C$. kathrynae constantly visiting flowers from $0900 \mathrm{~h}$ to $1600 \mathrm{~h}$ which corresponds to the diurnal display period of $M$. nivosa flowers on Mona Island. Flowers may be visited by several individuals at a given time (up to four beetles recorded simultaneously) with visits lasting up to 18.8 minutes. However, we believe that it is unlikely that $C$. kathrynae acts as a pollinator for several reasons. First, C. kathrynae adults were observed frequently inside flower corollas but exhibited minimum contact with the stigma and the stigmal lobes (Fig. 1D). Second, adults entered flowers before they opened, and the anthers were often seen disturbed and sometimes without pollen grains as if these had been removed or eaten following visits by $C$. kathrynae. In contrast to C. kathrynae in Florida, on Mona Island no evidence of association with scale insects (Hemiptera, Sternorrhyncha) was detected.

Although more research is needed to confirm the feeding preferences of C. kathrynae on Mona Island, our observations and videos suggest that this species may be feeding on M. nivosa pollen grains. Species of Cybocephalus are often reported as predators of other insects (especially predators of Hemiptera, Sternorrhyncha, Vinson 1959). Indeed, it is common for other beetle predators of plant-feeding Sternorrhyncha (i.e., Coccinellidae) to feed on pollen or nectar as an essential part of their diet, or to supplement dietary requirements, especially at times when prey are scarce (Giorgi et al. 2009). Furthermore, pollen-feeding does occur in the closely related and better known sap beetles (Nitidulidae). Meligethes aeneus (common pollen beetle) feeds on pollen both in its adult and larval stages (Cook et al. 2002), with adults feeding on pollen from a large variety of plants (Free \& Williams 1978). This species is considered a pest of oilseed rape (Brassica napus L.) where both adults and larvae feed on pollen from buds and flowers (Winfield 1992).

Future studies also need to test the potential effects of pollen consumption on Mammillaria flowers by C. kathrynae. Our videos of $C$. kathrynae in $M$. nivosa flowers also showed that flowers receive other visitors as well, which suggests that interactions are possible between $C$. kathrynae and other insect species. For example, a very small bee of the genus Lasioglosum (Apoidea) is also a consistent and frequent flower visitor of $M$. nivosa. Other flower visitors of $M$. nivosa include two small ant species, Solenopsis geminata Fabr. and Monomorium floricola Jerdon, but these species appear to be seasonal, appearing only in recordings between January and February 2009 but not in recordings made in June - August 2008.

Cybocephalus kathrynae has also been recently found on the Island of Puerto Rico, in a coastal dry scrub forest (Punta
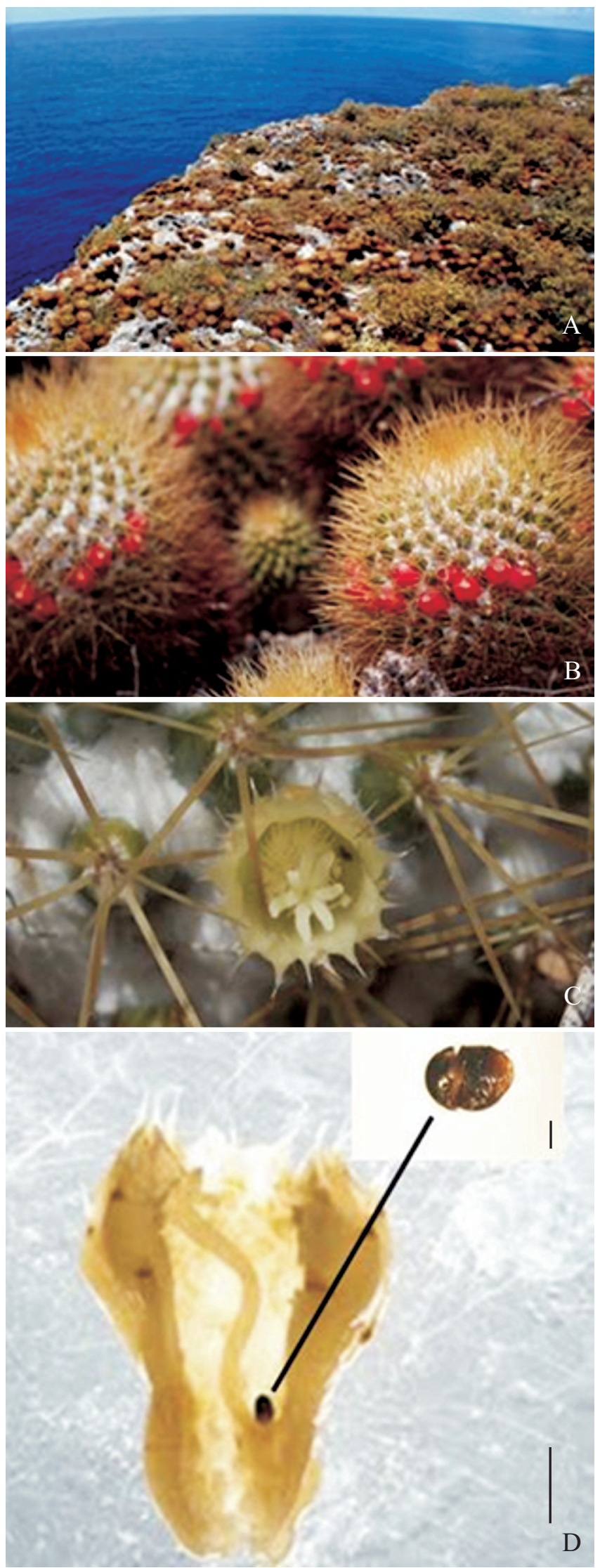

Fig. 1. Typical aggregation formed by Mammillaria nivosa on Mona Island (A). Plants displaying mature fruits (B) and a flower (C). Detail of Cybocephalus kathrynae within a flower of Mammillaria nivosa (D). 

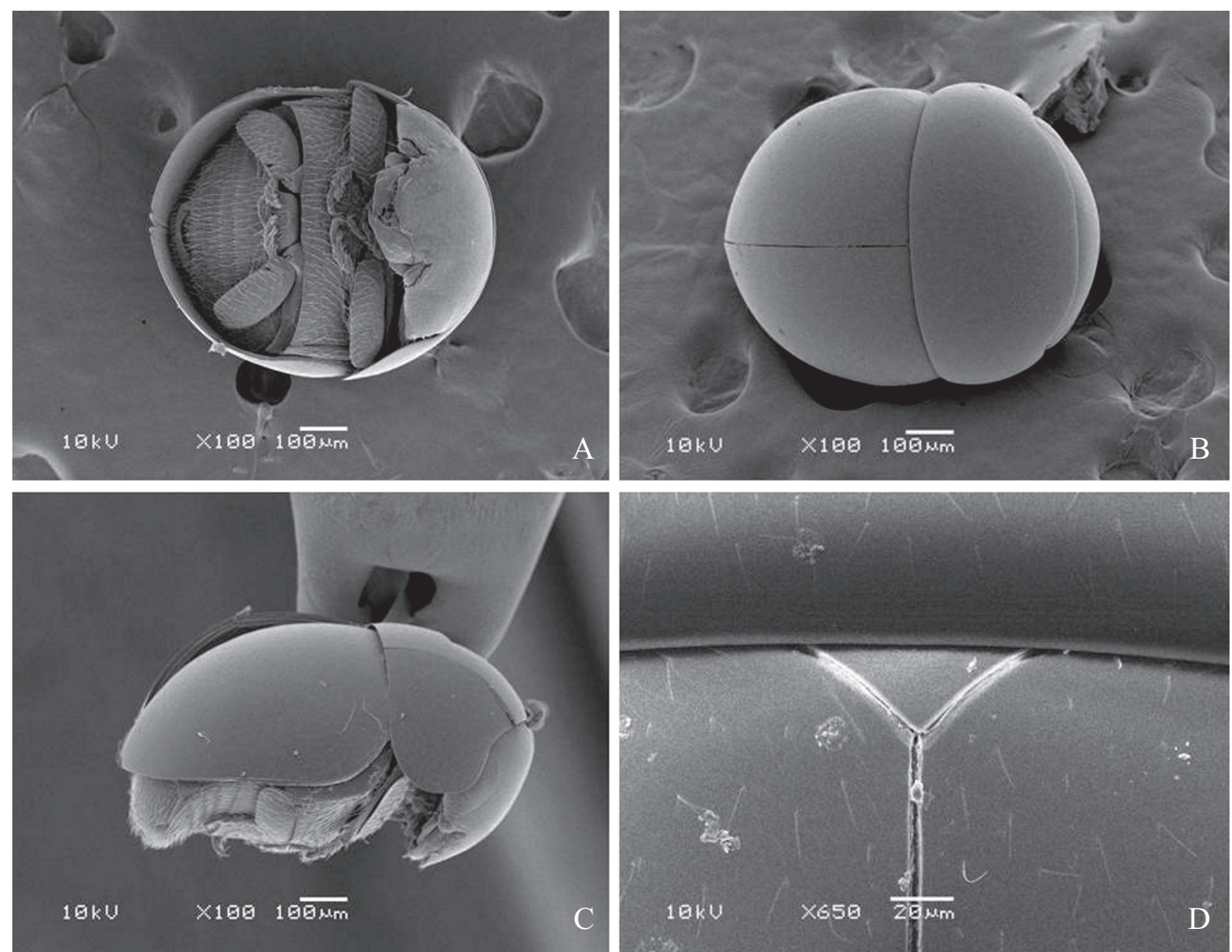

Fig. 2. Cybocephalus kathrynae: ventral view (A), dorsal view (B), lateral habitus (C), and scutellum (D).

Petrona, Salinas), feeding on the Harrisia cactus mealybug, Hypogeococcus pungens Granara de Willink (SegarraCarmona, pers. obs.). Thus, it appears that C. kathrynae may be more widely spread in the Caribbean than was originally thought. In Florida, C. kathrynae adults were collected by sifting sand and leaf litter in primary and secondary sand dunes (Smith \& Cave 2006). Mona Island is a calcareous platform that lies within the subtropical dry forest region with characteristic xeric vegetation (Ewel \& Whitmore 1973). Given the nature of reported habitats for C. kathrynae in Florida and in this study, we suggest that this species may be a natural component in arid environments.

\section{ACKNOWLEDGEMENTS}

We thank Trevor Smith (UFL-Gainesville) for the species identification and Waldemar Alcobas for pictures of Mammillaria. Camilo Gomides (UPR-Río Piedras) kindly translated the abstract and keywords to Portuguese. We also thank Lourdes Lastra, Aixa Tolentino, Laura Yunez, Betsabe Castro, and José Fumero for their contribution with fieldwork and Cristina Díaz at the Material Characterization Center at the University of Puerto Rico for technical support of the SEM imagery. This work was supported by NSF-UMEB (DBI-0602642) and NSF-CREST (HRD-0734826).

\section{REFERENCES}

Cook, S. M.; E. Bartlet; D. A. Murray \& I. H. Williams. 2002. The role of pollen odour in the attraction of pollen beetles to oilseed rape flowers. Entomologia Experimentalis et Applicata 104: 43-50.

Ewel, J. J \& J. L. Whitmore. 1973. The ecological life zones of Puerto Rico and U.S. Virgin Islands. USDA Forest Service, Institute of Tropical Forestry, Research Paper ITF-018. Available at: http://www.srs.fs.usda.gov/pubs/ rp/uncaptured/rp_itf018.pdf (accessed 16 February 2012).

Free, J. B. \& I. H. Williams. 1978. The responses of the pollen beetle, Meligethes aeneus, and the seed weevil, Ceuthorhynchus assimilis, to oil-seed rape, Brassica napus, and other plants. Journal of Applied Ecology 15: 761-774.

Giorgi, J. A.; N. J. Vandenberg; J. V. McHugh; J. A. Forrester; S. A. ZlipiDski; K. B. Miller; L. R. Shapiro \& M. F. Whiting. 2009. The evolution of food preferences in Coccinellidae. Biological Control 51: 215-231.

Smith, T. R. \& R. D. Cave. 2006. The Cybocephalidae (Coleoptera) of America north of Mexico. Annals of the Entomological Society of America 99: 776-792.

Vinson, J. 1959. The genus Cybocephalus Erichson in the Mascarene Islands (Coleoptera: Nitidulidae). Proceedings of the Royal Society of London B 28: 7-18.

Winfield A.L. 1992. Management of oilseed rape in Europe. Agricultural Zoology Reviews 5: 51-95.

Received 26/5/2011; accepted 9/2/2012

Editor: Marcela Laura Monné 